\title{
Does the fly matter? The CRACKPOT study in evidence based trout fishing
}

B J Britton, J Grimley Evans, J M Potter on behalf of the Collaborative Randomised And Controlled Kennet Piscatorial Options Trial (CRACKPOT) Investigators

John Radcliffe

Hospital, Oxford OX3 9DU

B J Britton, consultant surgeon Department of Clinical Geratology, Radcliffe Infirmary, Oxford OX2 6HE J Grimley Evans, professor

Wadham College, Oxford OX1 3PN

J M Potter, emeritus consultant neurosurgeon

Correspondence to: Professor Grimley

Evans

john.grimleyevans@ geratology.oxford.ac.u

BMJ 1998;317:1678-80

\begin{abstract}
Objective To investigate the importance of the type of dry fly (artificial floating fly) in catching trout (brown and rainbow) in an English chalkstream.

Setting River Kennet, Berkshire.

Design Five anglers on five separate occasions spent five hours using a randomly allocated fly from a sample of five types.

Participants Five anglers of considerable but varying experience, determination, and opinion.

Main outcome measures Number, weight, and species of trout caught.

Results One fly (Black Gnat) performed significantly worse than the others. The fly most successful in catching brown trout was the Cinnamon Sedge.

Conclusion The possible prolongation of doctors'

leisure time consequent on the use of unproductive trout flies has resource implications for the NHS.

Urgent funding of a definitive, large multiriver trial is needed.
\end{abstract}

\section{Introduction}

Fishing for trout with an artificial floating fly ("dry fly") is an ancient art, ${ }^{1}$ but the optimal design of fly remains a matter of controversy. Berners described 12 artificial fly dressings for different seasons. ${ }^{2}$ Walton recommended that the angler should also carry wool, fur, and feathers to the riverside to make imitations of the flies being taken by trout. ${ }^{3}$ Three centuries later in 1986 Buckland illustrated 354 patterns of dry fly in current use. ${ }^{4}$ Sceptics claim that a trout is less discriminating than the angler in choosing a fly, and may indeed not be able to tell one from another. Some fly patterns require materials of limited or even perilous provenance: “Tup's Indispensable," for example, calls for hairs from a ram's scrotum. The resource implications are considerable, and we report here a study aimed at introducing evidence based practice into an important area of medical activity.

\section{Methods}

Five medically qualified anglers took part. As a representative sample of past and present hospital consultant staff, all were male and of early or protracted middle age. The study was carried out on

Table 1 Numbers, species, and weights of trout caught, by angler

\begin{tabular}{|c|c|c|c|c|c|}
\hline \multirow[b]{2}{*}{ Angler } & \multicolumn{2}{|c|}{ Species } & \multirow[b]{2}{*}{ Total } & \multicolumn{2}{|c|}{ Weight (kg) } \\
\hline & Brown & Rainbow & & Total & Mean (range) \\
\hline$A$ & 5 & 5 & 10 & 7.56 & $0.76(0.48-1.39)$ \\
\hline$B$ & 11 & 4 & 15 & 10.68 & $0.71(0.51-0.85)$ \\
\hline $\bar{C}$ & 14 & 3 & 17 & 13.21 & $0.78(0.57-1.02)$ \\
\hline $\bar{D}$ & 7 & 5 & 12 & 9.01 & $0.75(0.51-0.91)$ \\
\hline $\bar{E}$ & 15 & 3 & 18 & 13.92 & $0.77(0.68-1.25)$ \\
\hline
\end{tabular}

the River Kennet, Berkshire, but the precise location is not revealed as some of the local poachers may subscribe to the $B M J$. The water supports a population of wild and stocked brown trout (Salmo trutta) and some rainbow trout (Oncorhynchus mykiss).

Methods were restricted to upstream dry fly fishing with a single hook. Five flies were chosen for evaluation: Grey Wulff, Silver Sedge, Parachute Adams, Black Gnat, Gold Ribbed Hare's Ear. All were purchased from a single supplier; the sedge was tied on a size 12 hook (the smallest available), the other patterns on size 14 . The study employed a randomised Latin square design. Blinding was problematical; a pilot study in which one investigator tried fishing without his spectacles proved hazardous, and concealing the nature of the fly from the trout was deemed futile as well as impractical. As a means of identifying observer bias, each angler recorded in advance his estimate of the utility of each fly on a scale of 0 (no hope) to 10 (full bag of fish expected), with 5 representing equipoise. At the start of the 1998 season, investigators received sealed, opaque envelopes numbered 1 to 5 , each containing a specification of the fly to be used on the first five successive forays to the river. The order of flies had been randomised for each angler by conventional blind selection from a hat. Fish were weighed to the nearest ounce ( $28 \mathrm{~g}$ ) by using a single balance and set of weights, each observer weighing his own fish. To comply with editorial requirements, weights have been converted to metric units.

\section{Statistical methods}

Analysis obviously had to include the Poisson distribution and Fisher's exact test. Final analysis was to be restricted to brown trout as rainbow trout are foreign and will probably eat anything.

\section{Economic analysis}

A cost-utility analysis using time trade off techniques was judged potentially embarrassing.

\section{Ethical approval}

The study was approved by the public bar ethics committee of the Riverside Inn, Canonbie, Dumfriesshire. All investigators gave fully informed consent. The water bailiff gave proxy consent on behalf of the trout.

\section{Results}

There were two departures from protocol. Firstly, shortly after the start of the study an investigator objected that, according to his 1886 edition of Halford, ${ }^{5}$ the flies supplied as Silver Sedge were actually Cinnamon Sedge. The data monitoring committee confirmed the misappellation but decided that the trial should proceed with substitution of Cinnamon for Silver Sedge. Investigators agreed that 
their prior utility estimates for the Silver Sedge were also appropriate for the Cinnamon. Secondly, investigators who were still working for their living found difficulty in providing a full five hours on each visit to the water. Examination of the data revealed that adjusting numbers of fish for time spent at the river made no difference to the results. This was attributable to the productivity of the evening rise, in which investigators shared more equitably, and to a proportion of retired members' days at the river being passed in somnolence and conviviality rather than fishing.

In the 25 angler sessions, 52 brown and 20 rainbow trout were landed. The biggest fish weighed $1.39 \mathrm{~kg}$, but all investigators reported the escape of several much larger fish. The number of fish reported as hooked but not landed differed significantly between anglers but not between flies (data invidious and not presented). Numbers and weights of catches are presented in table 1. Daily numbers are right censored as the bag limit is four fish. Fish weights are left censored as no fish less than $28 \mathrm{~cm}$ long is taken or angled for. Surprisingly, comparison of mean weights showed no evidence of interobserver measurement bias.

Table 2 Investigators' prior estimates of utility of each fly ( $0=$ no hope, $5=$ equipoise, $10=$ full bag of fish expected)

\begin{tabular}{lcc} 
Fly & Mean & Range \\
\hline Black Gnat & 6.6 & $2-10$ \\
\hline Gold Ribbed Hare's Ear & 5.6 & $3-8$ \\
\hline Grey Wulff & 8.8 & $7-10$ \\
\hline Parachute Adams & 6.4 & $5-10$ \\
\hline Cinnamon Sedge & 4.8 & $2-10$ \\
\hline
\end{tabular}

Table 2 sets out the investigators' prior utility estimates for each fly. Table 3 shows the catch for each of the five flies, and table 4 shows the distributions of numbers of fish caught at each session. There was no evidence of any relation between investigators' prior utility estimates and the numbers of fish they caught on each fly (Spearman's $r$ corrected for ties -0.06 , $\mathrm{P}>0.05$ ). In analysis of variance, differences between anglers in number of fish landed were not significant, at least statistically $(\mathrm{f}=1.67 ; \mathrm{df}=4,16 ; \mathrm{P}=0.20)$. The data suggest that the Black Gnat performed less well than the other flies, in catching only seven fish. Applying the Poisson distribution to the total catch per fly, the probability of seven or fewer fish was 0.025. Furthermore, the Black Gnat was associated with two sessions, involving two investigators, in which no fish were caught (table 4). No other fly produced a blank session, but only the Sedge provided five full bags.

The relation of fly and angler to the odds of catching a brown rather than a rainbow trout was examined in a logistic regression analysis. This showed no significant difference between anglers $\left(\chi^{2}=7.62, \mathrm{df}=4\right)$ but a significant relation with fly $\left(\chi^{2}=14.66, \mathrm{df}=4\right.$, $\mathrm{P}<0.005)$. With Fisher's exact test the Cinnamon Sedge differed significantly $(\mathrm{P}=0.005)$ from the pooled performance of the other flies in the catch of brown as distinct from rainbow trout.

\section{Discussion}

This study provides the first scientific evidence that trout can distinguish one fly from another. Conven-

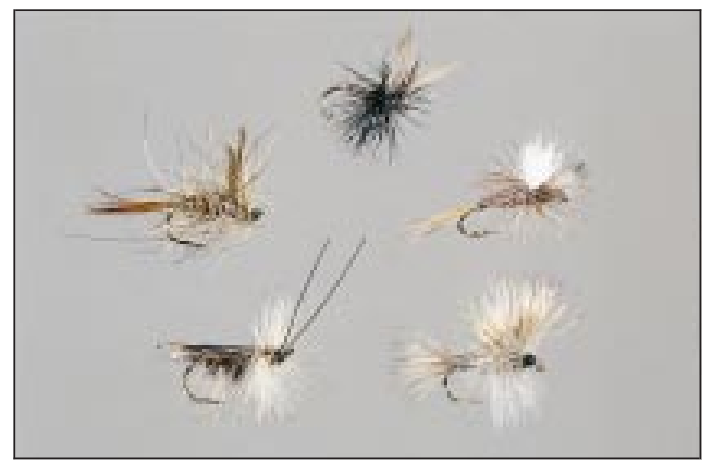

The five flies. From top in clockwise direction: Black Gnat, Parachute Adams, Grey Wulff, Cinnamon Sedge, and Gold Ribbed Hare's Ear

tional practice assumes that fish take the angler's fly in mistake for a natural insect on which they feed, but other factors have been suggested. Walton cites Sir George Hastings as claiming that the Fordidge trout of Kent took flies not for hunger but for wantonness. ${ }^{3}$ Contextual evidence suggests that the Fordidge trout were in fact salmon, but whether in wantonness or hunger Kennet trout seem to know a Black Gnat from a Cinnamon Sedge. Black gnat is a name vulgarly given to the terrestrial insect Bibio johannis, ${ }^{6}$ but the artificial fly of the name is also thought to be taken by trout in mistake for the flying ant. Both the bibio and the flying ant fall on the water in considerable numbers when blown off fields or when swarming but will in general present to trout only sporadically. Trout who have survived two thousand years of natural selection by fly fishermen might well regard the occasional black gnat as something to be avoided, however safely Nature's largesse, in the form of a swarm, may be savoured. No evidence exists that trout can count, and they will therefore register the existence of a swarm only when presented with the simultaneous rather than successive appearance of several examples of the same fly. Repetitive casting by an angler will therefore be ineffective.

In contrast with the Black Gnat, the other flies used in our study imitate flies whose appearance on the water is continuous and moderately frequent. The Gold Ribbed Hare's ear represents a hatching dun, the Grey Wulff an upwinged ephemerid, the Parachute Adams a spent imago, and the Cinnamon Sedge a caddis.

The second important finding of our study is the relative success of the Sedge pattern in catching brown

Table 3 Numbers, species, and weights of trout, by type of fly

\begin{tabular}{|c|c|c|c|c|c|}
\hline \multirow[b]{2}{*}{ Fly } & \multicolumn{2}{|c|}{ Species } & \multirow[b]{2}{*}{ Total } & \multicolumn{2}{|c|}{ Weight (Kg) } \\
\hline & Brown & Rainbow & & Total & Mean (range) \\
\hline Black Gnat & 5 & 2 & 7 & 6.14 & $0.88(0.55-1.02)$ \\
\hline Gold Ribbed Hare's Ear & 7 & 8 & 15 & 10.94 & $0.73(0.51-1.02)$ \\
\hline Grey Wulff & 14 & 3 & 17 & 13.13 & $0.75(0.51-1.25)$ \\
\hline Parachute Adams & 7 & 6 & 13 & 9.34 & $0.76(0.48-0.91)$ \\
\hline Cinnamon Sedge & 19 & 1 & 20 & 14.23 & $0.71(0.51-1.39)$ \\
\hline
\end{tabular}

Table 4 Number of trout landed in each session, by fly

\begin{tabular}{llllll} 
Fly & $\mathbf{0}$ & $\mathbf{1}$ & $\mathbf{2}$ & $\mathbf{3}$ & $\mathbf{4}$ \\
\hline Black Gnat & 2 & 1 & 1 & 0 & 1 \\
\hline Gold Ribbed Hare's Ear & 0 & 0 & 2 & 1 & 2 \\
\hline Grey Wulff & 0 & 1 & 0 & 0 & 4 \\
\hline Parachute Adams & 0 & 2 & 0 & 1 & 2 \\
\hline Cinnamon Sedge & 0 & 0 & 0 & 0 & 5
\end{tabular}


rather than rainbow trout. In contrast with the other three successful flies in this study, the Cinnamon Sedge is a close imitation of a particular genus (Limnephilus) rather than representing a broad impression of a range of flies. It is perhaps understandable that the brown trout, which has evolved in an environment of English chalkstreams and English anglers, should be more discriminating than the rainbow trout, which, although widely introduced in England in the past 50 years, evolved in tributaries of the Sacramento River in North America. ${ }^{7}$ As the rainbow trout rarely breeds in English waters, the opportunity for the species to develop skill in identifying flies by natural selection is limited.

It may be objected that our study is no more than a fishing expedition in that we had no agreed a priori hypothesis on the relative efficacy of the flies tested. Our results may therefore be regarded as hypothesis generating rather than hypothesis testing. Clearly, however, the possible prolongation of doctors' leisure time consequent on the use of unproductive trout flies has resource implications that the NHS may not readily bear. Our findings call for the urgent funding of a definitive, large multiriver trial.

We thank Stephen Jones for advice on the design, Jacqueline Birks for help with the analysis, and an anonymous reviewer for comments on an earlier draft. None of the investigators has any intention of taking the slightest notice of the results of this study.
Key messages

- Brown trout like a Cinnamon Sedge

- Black Gnats perform poorly

- Doctors are poor predictors of the utility of a fly

Contributors: BJB thought up and organised the trial. JGE analysed the results and wrote the paper. JMP trawled the archives of the Bodleian Library and contributed to the conviviality.J G G Ledingham and M S Dunnill (the two other members of the investigating group and of Merton College and New College, Oxford, respectively) helped with researching the literature and casting the flies.

Funding: None.

Competing interests: None declared.

1 Claudius Aelian. De animalium natura. Book 15. c. 200 AD. (Reprinted in Scholfield AF. On the characteristics of animals. London: Heinemann, 1959.)

Berners J. The treatyse of fyshinge with an angle. In: Wynkyn de Worde,

ed. The Boke of St Albans. 2nd ed. London: 1496. (Reprinted in Watkins MG. The treatyse of fyshinge with an angle. London: E Stock, 1880.)

3 Walton I. The compleat angler. London: 1653. (Reprinted in 1947 by J M Dent, London.)

Buckland J. The pocket guide to trout and salmon flies. London: Mitchell Beazley, 1986.

5 Halford FM. Floating flies and how to dress them. 2nd ed. London: Sampson Low, 1886.

6 Ronalds A. The flyfisher's entomology. London: Longman, Rees, Orme, Brown, Green, and Longman, 1836.

7 Frost WE, Brown ME. The trout. London: Collins, 1967.

\title{
Influence of superstition on the date of hospital discharge and medical cost in Japan: retrospective and descriptive study
}

\author{
Kenji Hira, Tsuguya Fukui, Akira Endoh, Mahbubur Rahman, Munetaka Maekawa
}

\section{Department of General Medicine and Clinical Epidemiology, Kyoto University, Sakyo-ku, Kyoto 606-8507, Japan Kenji Hira, postgraduate studen Tsuguya Fukui, professor \\ Mahbubur Rahman, postgraduate student Munetaka Maekawa, postgraduate student \\ Graduate School of Human and Environmental Studies, Kyoto University \\ Akira Endoh, postgraduate student \\ Correspondence to: Dr Hira \\ ken@kuhp. \\ kyoto-u.ac.jp}

BMJ 1998;317:1680-3

\begin{abstract}
Objectives To determine the influence of superstition about Taian (a lucky day)-Butsumetsu (an unlucky day) on decision to leave hospital. To estimate the costs of the effect of this superstition.

Design Retrospective and descriptive study. Setting University hospital in Kyoto, Japan. Subjects Patients who were discharged alive from Kyoto University Hospital from 1 April 1992 to 31 March 1995.

Main outcome measures Mean number, age, and hospital stay of patients discharged on each day of six day cycle.

Results The mean number, age, and hospital stay of discharged patients were highest on Taian and lowest on Butsumetsu (25.8 v 19.3 patients/day, $\mathrm{P}=0.0001$; 43.9 v 41.4 years, $\mathrm{P}=0.0001$; and 43.1 v 33.3 days, $\mathrm{P}=0.0001$ respectively). The effect of this difference on the hospital's costs was estimated to be 7.4 million yen $(£ 31000)$.

Conclusion The superstition influenced the decision to leave hospital, contributing to higher medical care costs in Japan. Although hospital stays need to be kept as short as possible to minimise costs, doctors should
\end{abstract}

not ignore the possible psychological effects on patients' health caused by dismissing the superstition.

\section{Introduction}

There are many superstitions in the world based on religion, old story, legend, fortune telling, and personal experience. Such superstitions influence people's behaviour in various social situations. In medicine, studies have been reported on Friday the 13th, the eight month fetus, and others. ${ }^{1-4}$ In Japan, Kaku reported that the superstition called Hinoe-Uma caused a significant increase in the induced abortion rate and a sharp decrease in the birthrate in $1966 . .^{5-9}$

Belief in Taian-Butsumetsu, a superstition relating to the six day lunar calendar, is common among Japanese people and affects various social events in everyday life. For example, people tend to have wedding ceremonies on Taian (a lucky day), avoiding Butsumetsu. The figure shows the six day cycle of the lunar calendar (Sensho, Tomobiki, Senpu, Butsumetsu, Taian, and Shakku) related to the solar (Gregorian) calendar system, which was adopted in Japan in 1873 . Despite this change Taian-Butsumetsu continued to gain popularity. ${ }^{10}$ 